\title{
Dampak Pembelajaran Daring terhadap Proses Belajar Anak Usia Dini
}

\author{
Nadia Hasanah Tsalisah ${ }^{\circledR}{ }^{\bowtie}$, Amir Syamsudin ${ }^{1}$ \\ Pendidikan Anak Usia Dini, Universitas Negeri Yogyakarta, Indonesia(1) \\ DOI: $10.31004 /$ obsesi.v6i3.1958
}

\begin{abstract}
Abstrak
Pandemi covid 19 yang terjadi mengharuskan anak untuk melakukan pembelajaran secara daring, hal ini dapat berdampak pada proses belajar anak usia dini. Tujuan peneliti untuk mengetahui dampak pembelajaran daring terhadap proses belajar anak usia dini. Metode yang digunakan dalam penelitian ini adalah penelitian kualitatif yang bersifat deskriptif. Data penelitian didapatkan melalui tinjauan pustaka dan studi empiris pada berbagai buku, dan jurnal penelitian sebelumnya. Hasil penelitian menunjukan bahwa anak mengalami penurunan motivasi ketika belajar, terdapat kendala dari orang tua anak yang ternyata masih kesulitan dalam membimbing anak belajar, kurangnya pemahaman materi dari orang tua, penggunaan gawai yang berlebihan pada anak menimbulkan efek negatif bagi kesehatan dan mental, serta menurunnya perilaku disiplin sehingga anak sering mengesampingkan tugas yang telah diberikan oleh guru, dan menjadi anak tidak taat dalam proses pembelajaran daring yang berlangsung.
\end{abstract}

Kata Kunci: pembelajaran daring; prosese belajar; anak usia dini

\begin{abstract}
The covid 19 pandemic that occurred requires children to do online learning, this can have an impact on the early childhood learning process. The researchers' goal is to find out the impact of online learning on the early childhood learning process. The method used in this study is qualitative research that is descriptivein. Research data is obtained through literature reviews and empirical studies on various books, and previous research journals. The results showed that children experience decreased motivation when learning, there are obstacles from parents of children who are still difficult in guiding children to learn, lack of understanding of material from parents, excessive use of gadgets in children has negative effects on health and mental, and decreased disciplinary behavior so that children often override tasks that have been given by teachers, and become a disobedient child in the online learning process that takes place.
\end{abstract}

Keywords: online learning; the learning process; Early childhood

Copyright (c) 2021 Nadia Hasanah Tsalisah, Amir Syamsudin.

$\triangle$ Corresponding author:

Email Address : nadiatsalisa@gmail.com (Lampung, Indonesia)

Received 16 October 2021, Accepted 29 December 2021, Published 17 January 2022 


\section{PENDAHULUAN}

Pemerintah Indonesia mengeluarkan berbagai kebijakan untuk menyikapi perluasaan pandemi COVID-19 (Coronavirus Disease-2019) demi mengurangi tingkat penyebarannya. Diantaranya larangan orang agar tidak berkumpul dan melaksanakan kegiatan di luar rumah menganjurkan agar tetap berada di rumah, beribadah di rumah, bekerja dari rumah (work from home), dan belajar dari rumah (school from home) (Handayani et al., 2021). Pandemi covid 19 mempengaruhi semua aspek kehidupan manusia termasuk bisnis, penelitian, pendidikan, kesehatan, ekonomi, olahraga, transportasi, ibadah, interaksi sosial, politik, pemerintahan, dan hiburan (Orfan \& Elmyar, 2020). Meluasnya penyebaran virus covid 19 mengakibatkan perubahan pada sistem pendidikan di Indonesia. Perubahan ini dirasakan oleh peserta didik yaitu adanya perubahan pada pola pembelajaran yang dilaksanakan secara daring. Pandemi mengakibatkan pembelajaran harus dilaksanakan secara daring untuk mencegah penularannya (Taradisa et al., 2020).

Pembelajaran daring merupakan pembelajaran yang berlangsung di dalam jaringan, guru dan siswa tidak bertatap muka secara langsung (Assidiqi \& Sumarni, 2020). Pembelajaran daring didefinisikan sebagai pembelajaran yang memanfaatkan teknologi informasi dan komunikasi. Pembelajaran daring dipahami sebagai pendidikan formal, diselenggarakan sekolah bagi siswa dan guru yang berada di lokasi terpisah sehingga memerlukan sistem telekomunikasi interaktif untuk menghubungkan keduanya dan berbagai sumber daya yang diperlukan (Ni'mah \& Setyawan, 2021). Penggabungan teknologi telah mengubah proses belajar mengajar dengan sistem pembelajaran daring, proses belajar dapat dilakukan tanpa mengenal waktu dan tempat (Chang et al., 2021). Pembelajaran daring memberikan metode pembelajaran yang efektif, seperti dalam berlatih dengan adanya umpan balik terkait, menggabungkan kolaborasi kegiatan belajar mandiri, personalisasi pembelajaran berdasarkan kebutuhan siswa yang menggunakan simulasi, dan permainan membantu perkembangan teknologi yang memungkinkan pembelajaran di dalam kelas dapat diakses di rumah maupun di lingkungan sekitarnya (Djaswadi, 2021). Selain itu pembelajaran daring dapat menjadi solusi atas penyelenggaraan pembelajaran pada masa pandemi (Nengrum et al., 2021). Namun studi lain menunjukkan bahwa pembelajaran daring tidak sebaik pembelajaran langsung, mayoritas siswa tidak menyukai pembelajaran daring dibandingkan dengan pembelajaran tatap muka (Noori, 2021). Studi yang dilakukan (Abbasi et al., 2020) mengungkapkan pengalaman pembelajaran online tidak cukup menarik karena keterbatasan menyebabkan kurangnya aspek praktis dalam mengajar.

Ketidakmaksimalan pembelajaran daring yang tersaji tentunya menimbulkan banyak permasalahan, khususnya pada anak-anak yang hakikatnya membutuhkan pembelajaran tatap muka (Yulia et al., 2021). Namun, proses pembelajaran daring tidak sepenuhnya tanggung jawab guru, karena guru tidak dapat memantau siswanya secara langsung satu persatu dari segi kedisiplinan belajarnya. Dari sinilah timbul masalah bahwa harus ada pengawasan orang tua dalam proses pembelajaran daring (Sari, 2021). Orang tua dituntut untuk mampu membimbing anak belajar dari rumah dan mampu menggantikan guru di sekolah, sehingga peran orang tua dalam tercapainya tujuan pembelajaran daring dan membimbing anak selama belajar di rumah dapat tercapai sesuai dengan tujuan pembelajaran (Wardani \& Ayriza, 2020).

Kenyataannya pembelajaran daring yang berlangsung mengakibatkan adanya kesulitan bagi orang tua untuk membimbing anak belajar. Orang tua belum terbiasa mengontrol aktivitas pembelajaran daring menjadi tersulut emosi sehingga terjadilah kekerasan pada anak, ditambah orang tua bekerja secara work from home dan mengerjakan pekerjaan rumah lainnya (Sutarna et al., 2021). Orang tua cenderung memberikan kekerasan verbal yang tidak disadari saat berlangsungnya pembelajaran secara daring, sehingga anak tidak tertarik untuk melakukan pembelajaran dan orang tua menganggap anaknya tidak mampu melakukan pembelajaran dari rumah. 
Kendala lainnya ditemukan dari pembelajaran daring bagi siswa usia 5-6 tahun yaitu orang tua terkadang tidak bisa sepenuhnya membantu karena terkendala waktu, pengetahuan, dan keahlian dalam teknologi, penyebabnya siswa usia ini masih memerlukan pendampingan secara utuh dari guru atau orang tua, namun masih banyak orang tua yang tidak memiliki smartphone untuk menunjang proses pembelajaran, penanaman nilai karakter tidak diajarkan di rumah, serta pembelajaran daring hanya bersifat pemberian tugas oleh guru karena terbatasnya cara memberikan pemahaman terhadap siswa (Napitupulu, 2020). Oleh karena itu sumber daya yang tidak memadai menjadi masalah dalam menjaga integritas akademik, masalah kebijakan, masalah teknis, kurangnya kepercayaan diri, dan kurangnya disiplin diri siswa menjadi tantangan utama dalam pelaksanaan proses pembelajaran daring selama pandemi covid 19 (Noori, 2021).

Kesuksesan dalam kegiatan pembelajaran daring adalah melalui sikap disiplin, setiap siswa akan menciptakan rasa nyaman dan aman untuk belajar baik bagi dirinya sendiri, maupun bagi siswa lain (Kurniasari, 2020). Kenyataan dilapangan pembelajaran daring selama pandemi, siswa pada umumnya mengalami penurunan dalam melakukan proses pembelajaran, siswa cenderung tidak antusias saat melakukan pembelajaran secara daring, penyebabnya adalah kebosanan pada siswa ketika tidak bertemu dengan temannya, pada umumnya siswa merasa bahwa tugas selama pandemi hanya membebani, karena menganggap ketika tidak bersekolah maka tidak perlu belajar (Sutarna et al., 2021). Hal ini menunjukan bahawa anak usia dini perlu adanya pendampingan dari orang tua dalam proses belajar agar tercapainya perkembangan yang optimal bagi anak usia dini saat pembelajaran daring berlangsung.

Anak usia dini memerlukan dukungan dan bantuan dari orang tua sebab, periode awal yang penting dan mendasar sepanjang rentang pertumbuhan serta perkembangan dalam kehidupan manusia. Namun, karena dampak dari pembelajaran daring yang dilaksanakan anak menjadi kurang fokus dalam proses belajar dan kesulitan dalam menangkap tugas yang diberikan oleh guru. Pembelajaran daring ditingkat pendidikan anak usia dini biasanya guru hanya memberikan tugas dan terkadang memberikan rekaman video pembelajaran kemudian materi yang disampaikan terlalu cepat sehingga anak sulit menangkap informasi dari materi yang sudah diberikan. Sehingga proses belajar anak usia dini hanya bergantung pada orang tua. Akan tetapi, orang tua terkadang tidak bisa sepenuhnya untuk membimbing anak untuk belajar, terlebih lagi orang tua yang banyak menghabiskan waktu untuk bekerja, dan orang tua yang gagap akan teknologi. Hal ini juga menjadi kendala dalam pembelajaran daring yang berlangsung saat ini. Tujuan dari penelitian ini adalah untuk mendapatkan informasi atau gamabaran mengenai dampak pembelajaran daring terhadap proses belajar anak usia dini. Apakah pembelajaran daring pada anak usia dini bisa dilakukan dengan baik dan efektif.

\section{METODOLOGI}

Metode yang digunakan dalam penelitian ini adalah penelitian kualitatif yang bersifat deskriptif. Data penelitian didapatkan melalui tinjauan pustaka dan studi empiris pada berbagai buku, dan jurnal penelitian sebelumnya yang berfokus pada dampak pembelajaran daring terhadap proses belajar anak usia dini. Pengumpulan data menggunakan mesin pencarian Google Scholar, ResearchGate, dan Science Direct. Penelitian ini menggunakan 4 jurnal internasional dan 28 jurnal nasional. Sehingga jumlah keseluruhan artikel yang digunakan 32 artikel ilmiah sebagai sumber data dengan detail pada tabel 1 (lampiran).

\section{HASIL DAN PEMBAHASAN}

Negara Indonesia menjadi salah satu yang terkena dampak pandemi covid 19. Kemunculan covid 19 sangat mempengaruhi kehidupan masyarakat dan menimbulkan banyak kepanikan. Ratusan bahkan ribuan manusia yang telah terinfeksi dan sudah banyak yang meninggal dunia akibat virus covid 19. Sehingga pemerintah Indonesia tidak tinggal 
diam, mulai dari memberikan banyak himbauan dan bantuan dalam mengatasi wabah covid 19 supaya berjalan efektif dan efisien dari akses kesehatan, pergaulan, hingga menyentuh pada ranah pendidikan yang merupakan unsur penting dalam mewujudkan generasi bangsa yang cerdas (Sasongko \& Hartanti, 2021).

Pandemi covid 19 yang sedang terjadi, mewajibkan setiap orang untuk membatasi segala aktivitas interaksi secara langsung dalam semua aspek kehidupan termasuk pada aspek pendidikan. Kebijakan ini menyentuh semua kalangan atau jenjang pendidikan, tidak terkecuali pada jenjang Taman Kanak-kanak (TK) (Sadikin \& Hamidah, 2020). Sehingga menyebabkan proses pembelajaran tidak dapat berlangsung seperti konsep ideal dalam sebuah proses pembelajaran. Pandemi covid 19 telah mengubah pola pembelajaran yang semestinya tatap muka menjadi pembelajaran jarak jauh atau biasa disebut pembelajaran daring. Munculnya pandemi covid 19 menjadikan kegiatan belajar mengajar yang semula dilaksanakan di sekolah kini menjadi belajar di rumah melalui daring. Pembelajaran daring yang dilakukan disesuaikan dengan kemampuan masing-masing sekolah, karena selama pembelajaran daring, Kemendikbud menyerahkan penyesuaian kurikulum kepada guru dan kepala sekolah sesuai dengan konsep merdeka belajar (Winarti et al., 2021).

Pelaksanaannya pembelajaran di rumah dengan metode daring tidaklah mudah. Faktor kurangnya semangat anak dan kurangnya kemampuan orang tua dalam mendampingi anak menjadi tantangan dalam penerapan metode pembiasaan. Tidak semua orang tua bisa menggunakan aplikasi pembelajaran yang baru, dan juga tidak banyak orang tua yang menggantikan sebagai guru di rumah. Orang tua sering tidak sabar dan tidak telaten dalam menghadapi anaknya di rumah yang kadang malah sering dibentak-bentak atau dimarahi yang dapat menimbulkan efek yang tidak baik bagi anak. Dengan situasi dan kondisi yang tidak kondusif tersebut membuat anak menjadi jenuh di rumah karena tidak bisa bertemu dengan teman-teman di sekolah seperti biasanya, menurunnya kedisiplinan anak, dan kurangnya motivasi untuk belajar. Pembelajaran di rumah cenderung monoton, karena biasanya di sekolah guru menyampaikan pembelajaran diselingi nyanyi, tepuk tangan, cerita dan dongeng serta kreatifitas lainnya. Emosi anak yang belum stabil dan belum bisa mengontrol dirinya dengan baik serta kemampuan komunikasi yang terbatas sehingga sulit menyampaikan apa yang dia rasakan. Dengan adanya perubahan atmosfer dan lingkungan serta tatanan baru, yang biasanya melakukan pembelajaran bersama teman-teman di sekolah yang sangat menyenangkan dan penuh kreatifitas, sekarang dengan tiba-tiba harus dilakukan sendiri di rumah dirasakan sangat kurang menarik, dan membosankan.

Pembelajaran daring yang berlangsung memberikan dampak pada anak, ditemukan beberapa permasalahan yang mempengaruhi proses belajar anak usia dini selama pembelajaran daring yaitu: menurunnya motivasi belajar, kendala dari orang tua, penggunaan gawai berlebihan, dan menurunnya perilaku disiplin dalam pembelajaran, adapun penjelasannya sebagai berikut:

\section{Menurunnya Motivasi Belajar}

Motivasi adalah suatu kondisi internal diri seseorang yang merupakan kesiapan untuk melakukan kegiatan, menimbulkan, mengarahkan, dan mengorganisasikan tingkah laku. Motivasi adalah serangkaian usaha untuk memberikan kondisi tertentu. Jadi seseorang ingin melakukan sesuatu, dan jika mereka tidak menyukainya, mereka akan berusaha untuk menghindari perasaan tidak suka (Puthree et al., 2021). Motivasi dan belajar merupakan dua hal yang saling mempengaruhi. Belajar adalah perubahan tingkah laku secara relatif permanen dan secara potensial terjadi sebagai hasil dari praktik atau penguatan yang dilandasi oleh tujuan untuk mencapai tujuan tertentu (Wahyuni et al., 2021). Iklim belajar yang dilaksanakan ketika pembelajaran daring mempengaruhi motivasi belajar anak. Kondisi pembelajaran daring menyebabkan guru kesulitan dalam mengontrol dan juga menjaga iklim belajar dikarenakan keterbatasan dalam ruang virtual. Kondisi tersebut menyebabkan motivasi belajar anak dapat menurun dan bahkan mempengaruhi hasil belajar anak (Cahyani 
et al., 2020). Berdasarkan hasil wawancara yang dilakukan Ni'mah \& Setyawan (2021) dengan beberapa guru bahwa, selama pembelajaran daring, motivasi belajar peserta didik menurun, dan hanya sedikit yang berpartisipasi secara aktif ketika pembelajaran. Hasil penelitian Wahyuni et al. (2021) menyatakan motivasi belajar anak di masa pandemi Covid 19 sudah berada pada kategori sedang yaitu sebanyak $78 \%$ orang tua menilai anak mereka tidak tinggi atau rendah motivasinya, namun dalam kategori sedang. Sedangkan menurut Puthree et al. (2021) rendahnya motivasi belajar siswa selama pembelajaran daring disebabkan yang pertama oleh faktor internal yaitu mengenai kesehatan fisik dan mental (emosional). Yang mana siswa menganggap belajar dari rumah sebagai liburan, sehingga mereka sering bermalas-malasan dan mudah jenuh dalam belajar dan mengerjakan tugas sekolah. Motivasi belajar anak dalam pembelajaran daring juga berkaitan dengan pola asuh orang tua, pola asuh orang tua yang tepat dan mendukung penuh kegiatan positif anak dapat membuat anak lebih termotivasi lagi dalam belajarnya (Fatmawati et al., 2021). Motivasi dan dukungan yang diberikan orang tua pada pembelajaran daring anak sangat penting dan berpengaruh terhadap proses pembelajarannya.

\section{Kendala dari Orang tua}

Pembelajaran daring juga memberikan dampak terhadap orang tua siswa, banyak orang tua yang kesulitan dalam menyesuaikan kondisi saat pembelajaran berlangsung. Karena orang tua turut berperan dalam pendampingan anak belajar secara daring. Dapat diketahui bahwa orang tua memiliki peran dalam keberlangsungan kegiatan pembelajaran daring. Peran orang tua berupa mendampingi selama berlangsungnya kegiatan pembelajaran, mengawasi anak dalam penggunaan smartphone, dan memberikan motivasi serta dukungan pada anak agar tidak bosan untuk belajar di rumah. Orang tua juga memiliki kewajiban untuk memberikan fasilitas yang menunjang dalam kegiatan pembelajaran seperti smartphone, kuota internet, dan earphone. Orang tua memiliki peranan penting dalam proses pembelajaran online pada anak (Chusna et al., 2021). Namun, orang tua tidak sepenuhnya dapat mendampingi anak dalam proses pembelajaran karena, orang tua harus tetap bekerja dalam kondisi pandemi covid 19. Berdasarkan penelitian (Pebriyanti, 2020) seorang ibu merasa bingung dan tidak bisa selalu membimbing anak ketika anak mempelajari materi dan mengerjakan tugas dari guru secara daring yang harus dilakukan di rumah, karena kesibukan ibu dalam menyelesaikan pekerjaan rumah tangga yang membuat seorang ibu kesulitan dalam membimbing anak. Kurangnya dorongan orang tua untuk anak terus belajar, sulitnya orang tua mengatur waktu mendampingi anak mengerjakan tugas sehingga tidak dapat memahami materi, dan anak tidak mencapai tujuan belajar (Nisa et al., 2021). Hasil penelitian yang dilakukan Wardani \& Ayriza (2020) secara umum kendala-kendala orang tua dalam mendampingi anak belajar di rumah di masa pandemi Covid-19 adalah kurangnya pemahaman materi oleh orang tua, kesulitan orang tua dalam menumbuhkan minat belajar anak, tidak memiliki cukup waktu untuk mendampingi anak karena harus bekerja, orang tua tidak sabar dalam mendampingi anak saat belajar dirumah, kesulitan orang tua dalam mengoperasikan gadget, dan kendala terkait jangkauan layanan internet. Sedangkan berdasarkan hasil penelitian Chusna et al. (2021) kendala orang tua dalam pembelajaran daring yakni ketiadaan sarana prasarana yang menunjang peserta didik yang berkaitan dengan latar belakang ekonomi orang tua, pemahaman orang tua yang kurang terkait mata pelajaran anak, ketidaksiapan orang tua dari segi waktu, media pembelajaran, komunikasi serta biaya, kendala terkait akses jaringan dan terbatasnya kuota yang digunakan, kurang bisa membangun motivasi anak selama pembelajaran daring. Solusi permasalahan pada orang tua mengenai pembelajaran daring terhadap anak yang pertama yaitu dengan 1) rutin melakukan komunikasi dengan anak, para orang tua, dan guru; 2) menyediakan waktu untuk mendampingi, dan mengawasi anak belajar; 3) meminta bantuan pada wali kelas untuk memberi informasi kemajuan belajar peserta didik; dan 4) meningkatkan penguasaan IT (Asmuni, 2020). 


\section{Penggunaan Gawai Berlebihan}

Gawai atau handphone merupakan bagian dari perkembangan teknologi yang selalu menghadirkan teknologi terbaru, dapat membantu berbagai kegiatan manusia menjadi lebih mudah. Ketika pandemi covid 19 mempengaruhi segala sektor pendidikan, penggunaan gawai sangat membantu khususnya dalam proses pembelajaran daring yang berlangsung. Pelaksanaan pembelajaran daring merupakan sebuah usaha yang dilakukan oleh sekolah untuk memberikan pembelajaran yang lebih bermakna dan sesuai dengan perkembangan zaman (Abdulatif \& Lestari, 2021). Walaupun banyak nilai positif yang diberikan, tetap saja terdapat pengaruh negatif yang ditimbulkan dari penggunaan gawai yang berlebihan ketika pembelajaran daring. Penggunaan gawai yang berlebihan secara berkelanjutan akan menimbulkan rasa ketergantungan bagi pemakainya. Gawai dengan fitur bermacam-macam dimanfaatkan orang tua agar anak mau duduk tenang menonton apa yang ada di gawai. Masih banyak orang tua yang tidak menyadari adanya dampak tersebut untuk anak. Karena pada faktanya banyak orang tua yang tidak mengawasi dan tidak memilah tontonan yang diberikan kepada anak. Akibatnya anak menjadi konsumtif dan pasif (Nafiah et al., 2021). Hasil penelitian Abdulatif \& Lestari (2021) menyatakan dampak dari anak yang kecanduan gadget akan lalai dengan tugasnya dalam belajar, akan terus bermain gadget dan anak akan acuh dengan lingkungan sekelilingnya. Bahkan anak tidak merespon bahkan membantah ketika dipanggil orang tuanya. Situasi ini dapat mengubah perilaku anak yang akan menarik diri dari kehidupan sosial dan dapat mengurangi disiplin serta rasa tanggung jawabnya. Anak lebih suka bermain bersama gadget dibandingkan bermain diluar bersama teman seumurannya. Gangguan pada perkembangan anak tidak akan begitu terlihat dalam jangka pendek, tetapi akan terlihat begitu jelas dalam jangka waktu panjang selama proses perkembangan anak berlangsung. Dengan penggunaan gawai yang berlebihan dapat menyebabkan menurunkan wawasan dan tingkat kecerdasan pada anak. Sedangkan hasil wawancara yang dilakukan Ni'mah \& Setyawan (2021) didapatkan data bahwa selain menggunakan gawai sebagai faktor pendukung untuk pembelajaran online, mereka menggunakan gawai untuk media sosial, youtube, dan juga untuk bermain game online. Hal ini menyebabkan penurunan disiplin para peserta didik, dimana waktu yang seharusnya digunakan untuk pembelajaran online akan tetapi malah digunakan untuk berselancar di media sosial dan bermain game online. Intensitas bermain game online yang berkaitan dengan lamanya waktu atau durasi dalam bermain, perhatian warga belajar terhadap permainan, serta emosi saat bermain akan memberikan pengaruh terhadap disiplin belajar pengguna game tersebut. Berdasarkan kondisi tersebut, seseorang yang bermain game secara terus menerus serta mengorbankan waktu dan juga pekerjaannya, banyak hal yang akan mempengaruhinya, salah satunya yaitu masalah disiplin belajar (Muraza \& Wisroni, 2020). Cara orang tua dalam menanggulangi anak dari kecanduan gawai diantaranya adalah dengan pendampingan, pengawasan, dan komunikasi terbuka (Goyena, 2019).

\section{Menurunnya Perilaku Disiplin}

Pembelajaran daring yang telah berjalan membawa dampak pada perilaku disiplin anak usia dini, ditemukan beberapa faktor yang mempengaruhi perilaku disiplin anak selama pembelajaran daring yaitu, menurunnya motivasi belajar, sarana prasarana kurang memadai, minimnya waktu luang orang tua, dan penggunaan gawai yang berlebihan ( $\mathrm{Ni}^{\prime}$ mah \& Setyawan, 2021). Pembelajaran daring yang dilaksanakan ternyata sangat berpengaruh terhadap perilaku siswa, siswa menjadi kurang bersosialisasi karena pembelajaran terbatas hanya di rumah tidak bertemu teman, siswa cenderung lebih emosional, siswa juga mengalami kekerasan verbal karena proses pembelajaran, siswa cenderung tidak disiplin dalam melakukan pembelajaran (Sutarna et al., 2021). Adapun penurunan perilaku disiplin pada siswa selama pandemi menurut Permatasari et al. (2021) antara lain, siswa telat bangun pada pagi hari, sehingga siswa terlambat dan tidak mengisi daftar hadir, terkadang mereka 
hanya bangun untuk mengisi daftar hadir serta tidak bersungguh-sungguh mengikuti pembelajaran daring, siswa sering terlambat dalam mengumpulkan tugas dan tidak tepat waktu dalam mengumpulkan tugas yang telah disepakati.

Menurunnya perilaku disiplin juga disebabkan kurangnya perhatian orang tua kepada anak ketika pembelajaran daring. Kemudian siswa lebih sering bermain handphone ataupun bermain dengan teman di lingkungan sekitar sehingga penumbuhan perilaku disiplin siswa mengalami penurunan (Permatasari et al., 2021). Hal ini terjadi karena penanaman perilaku disiplin yang sebelumnya dilaksanakan secara langsung di lingkungan sekolah dengan kontrol guru beralih menjadi dilaksanakan secara daring sehingga guru tidak bisa mengontrol siswa secara langsung. Perubahan tersebut menimbulkan beberapa permasalahan dalam pelaksanaan penanaman perilaku disiplin. Karena kedisiplinan belajar berperan penting terhadap siswa dimasa pembelajaran daring karena memberi dampak serius dalam bersikap dan berperilaku. Sebab itu siswa yang mempunyai kedisiplinan belajar pasti memiliki minat untuk terus belajar dan berusaha lebih optimal dibanding siswa yang kurang memiliki karakter kedisiplinan belajar (Nisa et al., 2021).

Disiplin adalah suatu perilaku yang menghormati, menghargai, patuh, terhadap peraturan yang berlaku, suatu bentuk ketaatan, dan pengendalian diri yang erat hubungannya dengan rasionalisme, sadar, dan tidak emosional (Rosdiana \& Choiriyah, 2021). Guru memiliki peran penting dalam membantu memaksimalkan perkembangan dan membentuk perilaku anak usia dini selama pandemi salah satunya disiplin. Perilaku disiplin yang terbentuk di sekolah terjadi melalui pembiasaan dan terbiasa terus menerus dilakukan. Disiplin merupakan metode pembentukan karakter serta pengajaran kontrol diri dan perilaku yang dianggap pantas (Permatasari et al., 2021). Hakekatnya, disiplin adalah perilaku yang dapat dilatih dengan mengedepankan pembiasaan berupa disiplin waktu dan perbuatan (Matussolikhah \& Rosy, 2021).

Hasil penelitian Nisa et al. (2021) bahwa perbedaan antara siswa yang memiliki karakter kedisiplinan belajar dan siswa yang tidak memiliki karakter kedisiplinan belajar terlihat pada kesadaran diri siswa untuk terus belajar di masa daring. Siswa yang memiliki karakter kedisiplinan belajar memang mempunyai minat dari dalam dirinya sendiri untuk selalu belajar dan selalu diberi dukungan oleh orang tuanya. Siswa yang tidak memiliki karakter kedisiplinan belajar membutuhkan dorongan dari orang tua untuk mendukung agar lebih semangat mengikuti kelas daring. Sedangkan menurut Matussolikhah \& Rosy (2021) perilaku disiplin belajar yang baik dapat mempengaruhi kontrol diri siswa ketika proses pembelajaran. Peserta didik yang menerapkan disiplin belajar dengan baik maka mampu bertanggung jawab terhadap tugasnya dan mengontrol dirinya meskipun tanpa pengawasan orang tua. Sehingga dengan terjadinya pandemi Covid-19 disiplin belajar sangat diperlukan, karena kegiatan pembelajaran dilakukan jarak jauh dan tanpa pengawasan dari guru. Didukung dengan penelitian selanjutnya Sutarna et al. (2021) pembelajaran daring terlalu lama membuat siswa merasa jenuh mengenai aktivitas yang dilakukan di rumah, hal ini menimbulkan kurangnya perilaku disiplin siswa saat pembelajaran daring, bahkan banyak yang menyelesaikan pembelajaran oleh orang tuanya, bukan oleh anak, penyebabnya adalah anak sudah tidak mau lagi atau sudah merasa bosan data mendapatkan penugasan dari guru. Namun berbeda dengan hasil penelitian Khatimah (2021) menunjukan bahwa perilaku disiplin anak selama sistem Belajar Dari Rumah (BDR) dilaksanakan di RA Al-Akhyar adalah anak didik telah berkembang yang ditunjukkan oleh dengan tercapainya dari enam indikator perilaku disiplin, yaitu: mengisi daftar hadir online tepat waktu, memakai pakaian rapi mengenakan seragam selama BDR, berdoa dengan tertib sebelum memulai pelajaran dan sesudah pembelajaran daring selama BDR, berusaha untuk mengerjakan tugas yang telah diberikan selama BDR dengan didampingi orang tua, menyelesaikan semua tugas yang diberikan oleh guru selama BDR berlangsung serta mengumpulkan tugas tepat waktu yang diberikan oleh guru sebelum pembelajaran online ditutup. Berdasarkan penelitian yang 
dilakukan Manazila \& Purwanti (2017) bahwa terdapat hubungan yang positif, kuat, dan signifikan antara motivasi belajar dan disiplin siswa.

Menanamkan perilaku disiplin bukanlah proses singkat, dibutuhkan proses yang panjang karena pendidikan bersifat berkelanjutan, sehingga menghasilkan perbaikan kualitas yang berkesinambungan agar perilaku baik dapat melekat dalam diri anak dan terbiasa dengan kegiatan tersebut serta menerapkannya dalam kehidupan sehari-hari. Menurut Rahmadi et al. (2017) disiplin seharusnya menjadi sikap yang harus ditanamkan dalam diri individu sejak usia dini, bahkan sesuatu yang menjadi bagian dari kehidupan seseorang untuk membentuk perilaku mereka sehari-hari.

\section{SIMPULAN}

Pembelajaran daring sangat berdampak terhadap proses belajar anak usia dini. Hasil penelitian menunjukan bahwa anak mengalami penurunan motivasi ketika belajar, kemudian terdapat kendala dari orang tua anak yang ternyata masih kesulitan dalam membimbing anak belajar, kurangnya pemahaman materi dari orang tua, penggunaan gawai yang berlebihan pada anak menimbulkan efek negatif bagi kesehatan dan mental, serta menurunnya perilaku disiplin sehingga anak sering mengesampingkan tugas yang telah diberikan oleh guru, dan menjadi anak tidak taat dalam proses pembelajaran daring yang berlangsung. Hasil penelitian ini dapat digunakan sebagai bahan referensi atau acuan dalam mengevaluasi pembelajaran daring, sehingga dampak yang terjadi pada pembelajaran daring dapat diatasi oleh orang tua, guru, atau stakeholder di dalam dunia pendidikan.

\section{UCAPAN TERIMAKASIH}

Puji syukur kepada Allah SWT atas rahmat dan karunia-Nya sehingga penulis dapat menyelesaikan karya ilmiah ini dengan baik. Penulisan karya ilmiah ini dapat diselesaikan tidak lepas dari bantuan dan kerjasama dengan pihak lain. Serta dosen pembimbing yang telah memberikan arahan dan masukan. Orang tua yang telah memberikan dukungan baik doa, motivasi, dan materi. Sehingga karya ilmiah ini dapat menambahkan pengetahuan bagi para pembaca dalam menghadapi pembelajaran daring di masa covid 19.

\section{DAFTAR PUSTAKA}

Abbasi, S., Ayoob, T., Malik, A., \& Memon, S. I. (2020). Perceptions of Students Regarding Elearning During Covid-19 at a Private Medical College. Pak J Med Sci, 36((COVID19S4)), S57-S61. https:// doi.org/10.12669/pjms.36.COVID19-S4.2766

Abdulatif, S., \& Lestari, T. (2021). Pengaruh Gadget Terhadap Perkembangan Sosial Anak di Masa Pandemi. Jurnal Pendidikan Tambusai, 5(1), 1490-1493.

Asmuni. (2020). Problematika Pembelajaran Daring di Masa Pandemi Covid-19 dan Solusi Pemecahannya. IkanJurnal Paedagogy: Jurnal Penelitian Dan Pengembangan Pendidikan, 7(4), 281-288. https://e-journal.undikma.ac.id/index.php/pedagogy https://doi.org/10.33394/jp.v7i4.2941

Assidiqi, M. H., \& Sumarni, W. (2020). Pemanfaatan Platform Digital di Masa Pandemi Covid19. Prosiding Seminar Nasional Pascasarjana, 298-303. https:// proceeding.unnes.ac.id/index.php/snpasca/article/download/601/519

Cahyani, A., Listiana, I. D., \& Larasati, S. P. D. (2020). Motivasi Belajar Siswa SMA pada Pembelajaran Daring di Masa Pandemi Covid-19. IQ (Ilmu Al-Qur'an): Jurnal Pendidikan Islam, 3(01), 123-140. https:/ / doi.org/10.37542/iq.v3i01.57

Chang, T. Y., Hsu, M. L., Kwon, J. S., Kusdhany, M. L. S., \& Hong, G. (2021). Effect of online learning for dental education in asia during the pandemic of COVID-19. Journal of Dental Sciences, 16(4), 1095-1101. https:/ / doi.org/10.1016/j.jds.2021.06.006 
Chusna, A., Zahra, A., Dermawan, K. I., Anggini, C. T., \& Eva, N. (2021). Problematika Orang Tua dalam Mendampingi Pembelajaran Daring Anak Selama Pandemi Covid-19 dan Solusi Pemecahannya. Prosiding Seminar Nasional (Senikopa), 83-97.

Djaswadi. (2021). Upaya Peningkatan Kompetensi Guru dalam Menerapkan Pembelajaran Daring Masa Pandemi Covid 19 dapat Meningkatkan Prestasi Belajar Peserta Didik. Journal of Insdustrial Engineering \& Management Research, 2(1), 156-179. http://www.jiemar.org. https:// doi.org/10.36841/consilium.v1i2.1208

Fatmawati, E., Ismaya, E. A., \& Setiawan, D. (2021). Pola Asuh Orang Tua dalam Memotivasi Belajar Anak pada Pembelajaran Daring. Jurnal Educatio, 7(1), 104-110. https://doi.org/10.31949/educatio.v7i1.871

Goyena, R. (2019). Peran Orangtua Dalam Pencegahan terhadap Kejadian Adiksi Gadget Pada Anak. Journal of Chemical Information and Modeling, 53(9), 1689-1699.

Handayani, F., Hibana, \& Surahman, S. (2021). Implementasi Pembelajaran Daring dan Luring bagi Anak Usia Dini pada Masa Pandemi Covid-19. Mitra Ash-Shibyan: Jurnal Pendidikan Dan Konseling, 4(02), 103-116. https:/ / doi.org/10.46963/mash.v4i02.358

Khatimah, H. (2021). Perilaku Disiplin Anak pada Pelaksanaan Belajar dari Rumah (BDR) Di Ra Al-Akhyar. TEMATIK: Jurnal Pemikiran Dan Penelitian Pendidikan Anak Usia Dini, 7(1), 52. https:// doi.org/10.26858/tematik.v7i1.20860

Kurniasari, A. dkk. (2020). Analisis Efektivitas Pelaksanaan Belajar Dari Rumah (BDR) Selama Pandemi COVID-19. Jurnal Review Pendidikan Dasar: Jurnal Kajian Pendidikan Dan Hasil Penelitian, 6(3), 1-8. http://journal.unesa.ac.id/index.php/PD

Manazila, A., \& Purwanti, E. (2017). Hubungan Motivasi Belajar dan Disiplin Siswa dengan Hasil Belajar PKn Kelas V. Joyful Learning Journal, 6(1), 61-70.

Matussolikhah, R., \& Rosy, B. (2021). Pengaruh Disiplin Belajar dan Gaya Belajar terhadap Hasil Belajar Siswa dalam Pembelajaran Daring di Masa Pandemi COVID-19. Jurnal Ilmiah Kependidikan, 2(2), 225-236. https:// doi.org/10.37478/jpm.v2i2.1030

Muraza, R. L., \& Wisroni. (2020). Hubungan antara Intensitas Bermain Game Online dengan Perilaku Disiplin Warga Belajar pada Pelatihan Otomotif. Jurnal Halaqah, 2(2), 173187. https:// doi.org/10.5281/zenodo.3819613

Nafiah, Q. N., Hibana, \& Surahman, S. (2021). Pengaruh Gadget Terhadap Perkembangan Kreativitas Anak Usia Dini Era Pandemi Covid-19. Jurnal Smart Paud, 4(2), 152-164.

Napitupulu, R. M. (2020). Dampak Pandemi Covid-19 terhadap Kepuasan Pembelajaran Jarak Jauh. Jurnal Inovasi Teknologi Pendidikan, 7(1), 23-33. https://doi.org/10.21831/jitp.v7i1.32771

Nengrum, T. A., Pettasolong, N., \& Nuriman, M. (2021). Kelebihan dan Kekurangan Pembelajaran Luring dan Daring dalam Pencapaian Kompetensi Dasar Kurikulum Bahasa Arab. Jurnal Pendidikan, 30(1), 1-12. https:// doi.org/10.32585/jp.v30i1.1190

Ni'mah, U., \& Setyawan, D. A. (2021). Online Learning: Analisis Faktor Penurunan Disiplin Peserta Didik Selam Masa Pandemi Covid-19. Jurnal Paedagogia, 10(1), 33-48. http://jurnalpaedagogia.com/index.php/pdg/article/view/134/65

Nisa, F., Fathurohman, I., \& Setiawan, D. (2021). Karakter Kedisiplinan Belajar Anak SDN 2 Mryolobo Pada Masa Pembelajaran Daring. Jurnal Inovasi Penelitian, 2(4), 1179-1186.

Noori, A. Q. (2021). The impact of COVID-19 pandemic on students' learning in higher education in Afghanistan. Heliyon, 7(10), e08113. https://doi.org/10.1016/j.heliyon.2021.e08113

Orfan, S. N., \& Elmyar, A. H. (2020). Public Knowledge, Practices and Attitudes Towards Covid-19 in Afghanistan. Public Health of Indonesia, 6(4), 104-115. https://doi.org/10.36685/phi.v6i4.356

Pebriyanti, S. (2020). Implementasi Rational Emotive Behavior Therapy pada Orangtua dalam Mendampingi Anak Belajar Masa Covid-19. Golden Age: Jurnal Ilmiah Tumbuh Kembang Anak Usia Dini, 5(2), 63-70. https:// doi.org/10.14421/jga.2020.52-03 
Permatasari, N. A., Setiawan, D., \& Kironoratri, L. (2021). Model Penanaman Karakter Disiplin Siswa Sekolah Dasar pada Masa Pembelajaran Daring. Edukatif: Jurnal Ilmu Pendidikan, 3(6), 3758-3768. https:// doi.org/10.31004/edukatif.v3i4.642

Puthree, A. N., Rahayu, D. W., Ibrahim, M., \& Djazilan, M. S. (2021). Analisis Faktor Penyebab Rendahnya Motivasi Belajar Siswa Sekolah Dasar selama Pembelajaran Daring. Jurnal Basicedu, 5(3), 1683-1688. https:// doi.org/10.31004/basicedu.v5i5.1279

Rahmadi, R. T., Zulaihati, S., \& Susanti, S. (2017). The Influence of Learning Discipline and Peer Environment on Learning Outcomes of Business Economy in Class X at One of SMK Negeri in Jakarta. Jurnal Pendidikan Ekonomi Dan Akuntansi, 1(1), 1-13. http://pub.unj.ac.id/index.php/jpepa/article/view/30

Rosdiana, D., \& Choiriyah. (2021). Pengaruh Pembelajaran Daring Selama Pandemi Terhadap Kedisiplinan Anak Usia 6-7. Pendidikan Tambusai, 5(3), 6703-6708.

Sadikin, A., \& Hamidah, A. (2020). Pembelajaran Daring di Tengah Wabah Covid-19. Biodik, 6(2), 109-119. https:// doi.org/10.22437/bio.v6i2.9759

Sari, S. W. (2021). Pengaruh Pengawasan Orang Tua terhadap Disiplin Belajar Siswa di Masa Pandemi Covid19. Almufi Jurnal Pendidikan, 1(2), 51-54.

Sasongko, H., \& Hartanti, C. D. (2021). Manajemen Kreativitas Pengajaran Musik Pendidikan Anak Usia Dini di Masa Pandemi Covid 19 musik. IJEC: Jurnal Dunia Anak Usia Dini, 3(1), 17-32. https://doi.org/10.35473/ijec.v3i1.830

Sutarna, N., Acesta, A., Cahyati, N., Giwangsa, S. F., Iskandar, D., \& Harmawati, H. (2021). Dampak Pembelajaran Daring terhadap Siswa usia 5-8 tahun. Jurnal Obsesi : Jurnal Pendidikan Anak Usia Dini, 6(1), 288-297. https://doi.org/10.31004/obsesi.v6i1.1265

Taradisa, N., Jarmita, N., \& Emalfida, E. (2020). Kendala Yang Dihadapi Guru Mengajar Daringpada Masa Pandemi Covid-19. Jurnal Keilmuan Dan Kependidikan Dasar, 12(02), 141-154.

Wahyuni, S., Putri, A. A., \& Fadillah, S. (2021). Motivasi Belajar Anak Usia Dini pada Program Belajar dari Rumah di Masa Pandemi COVID-19. Incrementapedia: Jurnal Pendidikan $\begin{array}{llll}\text { Anak Usia } & \text { 12-21. }\end{array}$ https:// doi.org/10.36456/incrementapedia.vol3.no01.a3754

Wardani, A., \& Ayriza, Y. (2020). Analisis Kendala Orang Tua dalam Mendampingi Anak Belajar di Rumah pada Masa Pandemi Covid-19. Jurnal Obsesi : Jurnal Pendidikan Anak Usia Dini, 5(1), 772. https:// doi.org/10.31004/obsesi.v5i1.705

Winarti, S., Taib, B., Alhadad, B., \& Achmad, F. (2021). Analisis Dampak Covid-19 dalam Proses Pembelajaran Daring. Jurnal Ilmiah Cahaya Paud, 3(1), 150-159. https:// doi.org/10.33387/cp.v3i1.3140

Yulia, R., Mayar, F., \& Safrizal. (2021). Dampak Pembelajaran Daring Di Taman Kanak-Kanak Terhadap Sense of Belonging Siswa Pada Taman, Sekolah, dan Guru. Indonesian Journal of Early Childhood: Jurnal Dunia Anak Usia Dini, 3(2). https:// doi.org/10.35473/ijec.v3i2.926 
Tabel 1. Rangkuman Artikel Penelitian

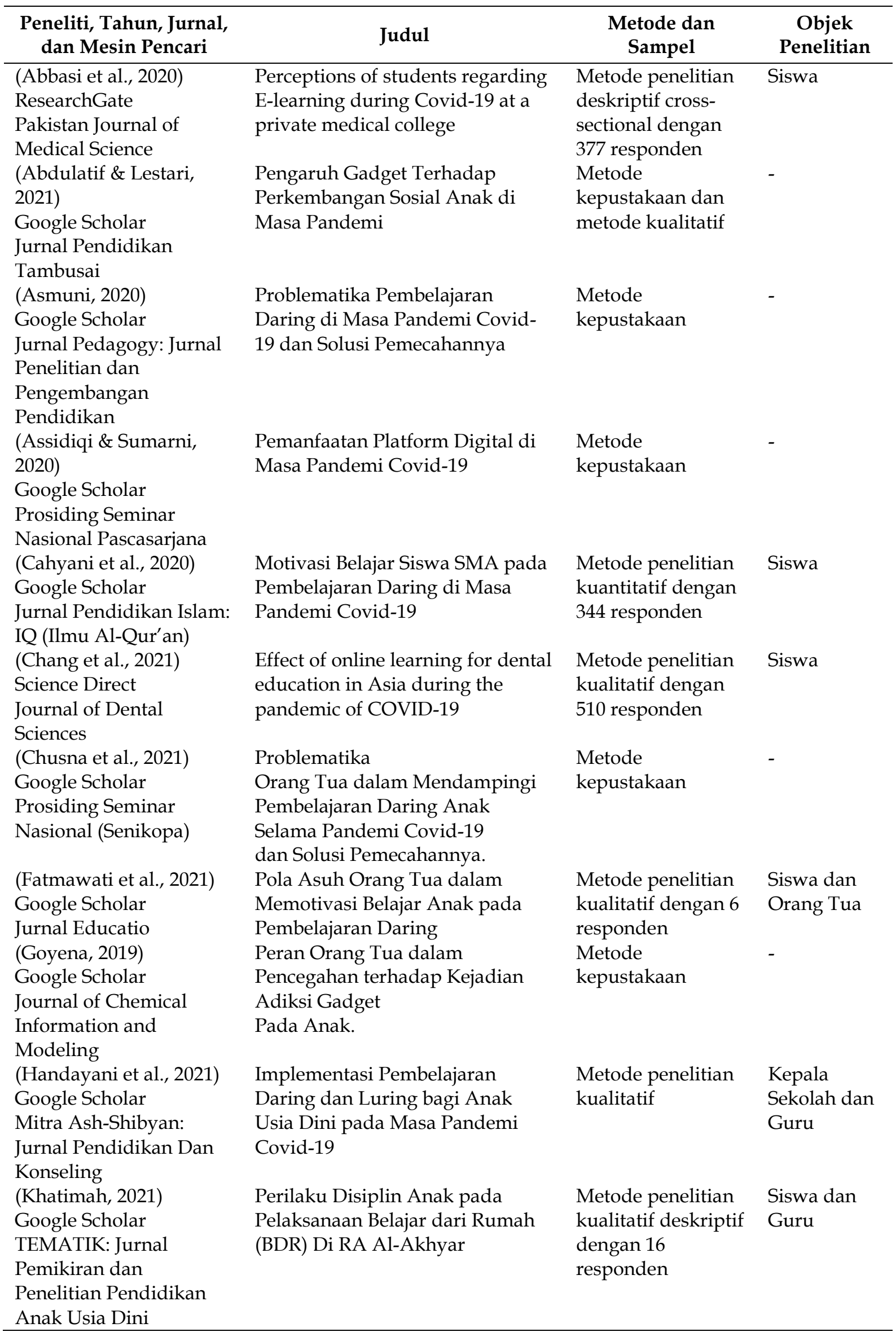




\begin{tabular}{|c|c|c|c|}
\hline $\begin{array}{c}\text { Peneliti, Tahun, Jurnal, } \\
\text { dan Mesin Pencari }\end{array}$ & Judul & $\begin{array}{l}\text { Metode dan } \\
\text { Sampel }\end{array}$ & $\begin{array}{c}\text { Objek } \\
\text { Penelitian }\end{array}$ \\
\hline (Manazila dan Purwanti, & Hubungan Motivasi Belajar dan & Metode penelitian & Siswa \\
\hline 2017) & Disiplin Siswa dengan Hasil & kuantitatif dengan & \\
\hline Google Scholar & Belajar PKn Kelas V & 134 responden & \\
\hline \multicolumn{4}{|l|}{ Joyful Learning Journal } \\
\hline (Matussolikhah \& Rosy, & Pengaruh Disiplin Belajar dan & Metode penelitian & \multirow[t]{5}{*}{ Siswa } \\
\hline 2021) & Gaya Belajar terhadap Hasil & kuantitatif dengan & \\
\hline Google Scholar & Belajar Siswa dalam Pembelajaran & 105 responden & \\
\hline Jurnal Ilmiah & Daring di Masa Pandemi COVID- & & \\
\hline Kependidikan & 19 & & \\
\hline (Muraza \& Wisroni, & Hubungan antara Intensitas & Metode penelitian & \multirow[t]{4}{*}{ Siswa } \\
\hline 2020) & Bermain Game Online dengan & kuantitatif dengan & \\
\hline Google Scholar & Perilaku Disiplin Warga Belajar & 75 responden & \\
\hline Jurnal Halaqah & pada Pelatihan Otomotif & & \\
\hline (Nafiah et al., 2021) & Pengaruh Gadget terhadap & Metode penelitian & \multirow[t]{3}{*}{ Orang Tua } \\
\hline Google Scholar & Perkembangan Kreativitas Anak & kualitatif deskriptif & \\
\hline Jurnal Smart Paud & Usia Dini Era Pandemi Covid-19 & $\begin{array}{l}\text { dengan } 6 \\
\text { responden }\end{array}$ & \\
\hline (Napitupulu, 2020) & Dampak Pandemi Covid-19 & Metode penelitian & \multirow[t]{4}{*}{ Siswa } \\
\hline Google Scholar & terhadap Kepuasan Pembelajaran & kualitatif deskriptif & \\
\hline Jurnal Inovasi Teknologi & Jarak Jauh & dengan 384 & \\
\hline Pendidikan & & responden & \\
\hline (Nengrum et al., 2021) & Kelebihan dan Kekurangan & Metode penelitian & Siswa dan \\
\hline $\begin{array}{l}\text { Google Scholar } \\
\text { Jurnal Pendidikan }\end{array}$ & $\begin{array}{l}\text { Pembelajaran Luring dan Daring } \\
\text { dalam Pencapaian Kompetensi } \\
\text { Dasar Kurikulum Bahasa Arab. }\end{array}$ & kualitatif & Guru \\
\hline (Ni'mah \& Setyawan, & Online Learning : Analisis Faktor & Metode penelitian & \multirow{4}{*}{$\begin{array}{l}\text { Siswa, Guru, } \\
\text { dan Orang } \\
\text { Tua }\end{array}$} \\
\hline 2021) & Penurunan Disiplin Peserta Didik & kualitatif deskriptif & \\
\hline Google Scholar & Selam Masa Pandemi Covid-19 & & \\
\hline Jurnal Paedagogia & & & \\
\hline (Nisa et al., 2021) & Karakter Kedisiplinan Belajar & Metode penelitian & \multirow{3}{*}{$\begin{array}{l}\text { Siswa, Guru, } \\
\text { dan Orang } \\
\text { Tua }\end{array}$} \\
\hline Google Scholar & Anak SDN 2 Mryolobo Pada Masa & kualitatif deskriptif & \\
\hline Jurnal Inovasi Penelitian & Pembelajaran Daring & & \\
\hline (Noori, 2021) & The impact of COVID-19 & Metode penelitian & \multirow[t]{3}{*}{ Siswa } \\
\hline Science Direct & pandemic on students' learning in & kuantitatif dengan & \\
\hline Heliyon & higher education in Afghanistan & 592 responden & \\
\hline (Orfan \& Elmyar, 2020) & Public Knowledge, Practices and & Metode penelitian & \multirow[t]{3}{*}{ Siswa } \\
\hline Science Direct & Attitudes Towards Covid-19 in & kuantitatif dengan & \\
\hline $\begin{array}{l}\text { Public Health of } \\
\text { Indonesia }\end{array}$ & Afghanistan & 1472 responden & \\
\hline (Permatasari et al., 2021) & Model Penanaman Karakter & Metode penelitian & Siswa dan \\
\hline Google Scholar & Disiplin Siswa Sekolah Dasar & kualitatif deskriptif & \multirow[t]{3}{*}{ Guru } \\
\hline $\begin{array}{l}\text { Edukatif: Jurnal Ilmu } \\
\text { Pendidikan }\end{array}$ & pada Masa Pembelajaran Daring & $\begin{array}{l}\text { dengan } 6 \\
\text { responden }\end{array}$ & \\
\hline $\begin{array}{l}\text { Pendidikan } \\
\text { (Puthree et al., 2021) }\end{array}$ & & $\begin{array}{l}\text { responden } \\
\text { Metode penelitian }\end{array}$ & \\
\hline $\begin{array}{l}\text { (Puthree et al., 2021) } \\
\text { Google Scholar }\end{array}$ & $\begin{array}{l}\text { Analisis Faktor Penyebab } \\
\text { Rendahnva Motivasi Belajar Siswa }\end{array}$ & $\begin{array}{l}\text { Metode penelitian } \\
\text { kualitatif deskriptif }\end{array}$ & \multirow{4}{*}{ Guru } \\
\hline Google Scholar & Rendahnya Motivasi Belajar Siswa & kualitatif deskriptif & \\
\hline Jurnal Basicedu & Sekolah Dasar selama & dengan 4 & \\
\hline & Pembelajaran Daring & responden & \\
\hline (Rahmadi et al., 2017) & The Influence of Learning & Metode penelitian & \multirow[t]{5}{*}{ Siswa } \\
\hline Google Scholar & Discipline and Peer Environment & kuantitatif dengan & \\
\hline Jurnal Pendidikan & on Learning Outcomes of & 147 responden & \\
\hline Ekonomi Dan Akuntansi & Business Economy in Class $\mathrm{X}$ at & & \\
\hline & One of SMK Negeri in Jakarta & & \\
\hline (Rosdiana \& Choiriyah, & Pengaruh Pembelajaran Daring & Metode penelitian & \multirow[t]{3}{*}{ Siswa } \\
\hline 2021) & Selama Pandemi Terhadap & kuantitatif dengan & \\
\hline Google Scholar & Kedisiplinan Anak Usia 6-7 & 37 responden & \\
\hline
\end{tabular}




\begin{tabular}{|c|c|c|c|}
\hline $\begin{array}{l}\text { Peneliti, Tahun, Jurnal, } \\
\text { dan Mesin Pencari }\end{array}$ & Judul & $\begin{array}{l}\text { Metode dan } \\
\text { Sampel }\end{array}$ & $\begin{array}{c}\text { Objek } \\
\text { Penelitian }\end{array}$ \\
\hline \multicolumn{4}{|l|}{$\begin{array}{l}\text { Jurnal Pendidikan } \\
\text { Tambusai }\end{array}$} \\
\hline $\begin{array}{l}\text { (Sadikin \& Hamidah, } \\
\text { 2020) } \\
\text { Google Scholar } \\
\text { Biodik }\end{array}$ & $\begin{array}{l}\text { Pembelajaran Daring di Tengah } \\
\text { Wabah Covid-19 }\end{array}$ & $\begin{array}{l}\text { Metode penelitian } \\
\text { kualitatif dengan } \\
96 \text { responden }\end{array}$ & Siswa \\
\hline $\begin{array}{l}\text { (Sari, 2021) } \\
\text { Google Scholar } \\
\text { Almufi Jurnal }\end{array}$ & $\begin{array}{l}\text { Pengaruh Pengawasan Orang Tua } \\
\text { terhadap Disiplin Belajar Siswa di } \\
\text { Masa Pandemi Covid19 }\end{array}$ & $\begin{array}{l}\text { Metode penelitian } \\
\text { kuantitatif dengan } \\
35 \text { responden }\end{array}$ & Siswa \\
\hline $\begin{array}{l}\text { Pendidikan } \\
\text { (Sutarna et al., 2021) } \\
\text { Google Scholar } \\
\text { Jurnal Obsesi : Jurnal } \\
\text { Pendidikan Anak Usia } \\
\text { Dini }\end{array}$ & $\begin{array}{l}\text { Dampak Pembelajaran Daring } \\
\text { terhadap Siswa usia 5-8 tahun }\end{array}$ & $\begin{array}{l}\text { Metode penelitian } \\
\text { kualitatif }\end{array}$ & Siswa \\
\hline $\begin{array}{l}\text { (Wahyuni et al., 2021) } \\
\text { Google Scholar } \\
\text { Incrementapedia: Jurnal } \\
\text { Pendidikan Anak Usia } \\
\text { Dini }\end{array}$ & $\begin{array}{l}\text { Motivasi Belajar Anak Usia Dini } \\
\text { pada Program Belajar dari Rumah } \\
\text { di Masa Pandemi COVID-19 }\end{array}$ & $\begin{array}{l}\text { Metode penelitian } \\
\text { kuantitatif dengan } \\
27 \text { responden }\end{array}$ & Siswa \\
\hline $\begin{array}{l}\text { (Wardani \& Ayriza, } \\
\text { 2020) }\end{array}$ & $\begin{array}{l}\text { Analisis Kendala Orang Tua } \\
\text { dalam Mendampingi Anak Belajar }\end{array}$ & $\begin{array}{l}\text { Metode penelitian } \\
\text { studi kasus dengan }\end{array}$ & Orang Tua \\
\hline $\begin{array}{l}\text { Google Scholar } \\
\text { Jurnal Obsesi : Jurnal } \\
\text { Pendidikan Anak Usia } \\
\text { Dini }\end{array}$ & $\begin{array}{l}\text { di Rumah pada Masa Pandemi } \\
\text { Covid-19 }\end{array}$ & 12 responden & \\
\hline $\begin{array}{l}\text { (Winarti et al., 2021) } \\
\text { Google Scholar } \\
\text { Jurnal Ilmiah Cahaya } \\
\text { Paud }\end{array}$ & $\begin{array}{l}\text { Analisis Dampak Covid-19 dalam } \\
\text { Proses Pembelajaran Daring }\end{array}$ & $\begin{array}{l}\text { Metode penelitian } \\
\text { kualitatif deskriptif } \\
\text { dengan } 5 \\
\text { responden }\end{array}$ & $\begin{array}{l}\text { Orang Tua } \\
\text { dan Guru }\end{array}$ \\
\hline Yulia et al., 2021 & Dampak Pembelajaran Daring Di & Metode penelitian & Siswa dan \\
\hline $\begin{array}{l}\text { Google Scholar } \\
\text { Indonesian Journal of } \\
\text { Early Childhood: Jurnal } \\
\text { Dunia Anak Usia Dini }\end{array}$ & $\begin{array}{l}\text { Taman Kanak-Kanak Terhadap } \\
\text { Sense of Belonging Siswa Pada } \\
\text { Taman, Sekolah, dan Guru }\end{array}$ & $\begin{array}{l}\text { kualitatif deskriptif } \\
\text { dengan } 6 \\
\text { responden }\end{array}$ & Orang Tua \\
\hline
\end{tabular}

